\title{
GAMBARAN STATUS KARIES PADA SISWA SMP NEGERI I TOMOHON
}

\author{
${ }^{1}$ Elisa Mangkey \\ ${ }^{2}$ Jimmy Posangi \\ ${ }^{3}$ Michael A. Leman
}

\author{
${ }^{1}$ Kandidat Skripsi Program Studi Pendidikan Dokter Gigi Fakultas Kedokteran \\ ${ }^{2}$ Bagian Farmakologi dan Terapi Fakultas Kedokteran \\ ${ }^{3}$ Bagian Konservasi Gigi Program Studi Pendidikan Dokter Gigi Fakultas Kedokteran \\ Universitas Sam Ratulangi Manado \\ Email: lisa26widya@yahoo.com
}

\begin{abstract}
The most common oral disease in society is dental caries. Dental caries is a disease in hard tissue of tooth such as enamel, dentin, and cementum caused by microbiological activity inside fermented carbohydrate. SMP Negeri 1 Tomohon is one of the large junior high schools with students aged 11-14 years, and their parents' social economy variated from low to middle class. Moreover, there are lot of snack counters around the school. Children's habit of consuming cariogenic foods makes them susceptible to dental caries. This study aimed to obtain dental caries status on students at SMP Negeri 1 Tomohon. This was a descriptive research with cross sectional approach method. Population of this study was students in SMP Negeri 1 Tomohon with sampling using purposive sampling technique and there are 92 students became this research sample. Caries status was measured by using DMF-T index (decayed, missing, filling-teeth) which firstly acquainted by Klein H., Palmer CE, and Knutson JW in 1983. The result of this research showing DMF-T on SMP Negeri 1 Tomohon is $\mathrm{D}$ (decayed) scored 165, M (missing) scored 39, and F (filling) scored 4 . The average result of DMF-T was 2.26. Conclusion: Caries status of SMP Negeri 1 Tomohon students was in the low category.
\end{abstract}

Keywords: caries status, junior high school students, DMF-T

\begin{abstract}
Abstrak: Penyakit gigi dan mulut yang paling banyak dijumpai di masyarakat luas yaitu karies gigi. Karies gigi merupakan suatu penyakit pada jaringan keras gigi berupa email, dentin dan sementum yang disebabkan oleh aktivitas jasad renik yang ada dalam suatu karbohidrat yang diragikan. SMP Negeri 1 Tomohon merupakan salah satu sekolah yang cukup besar dengan siswa berusia 11-14 tahun, status sosial ekonomi orang tua yang bervariasi dari golongan rendah sampai menengah, dan terdapat banyak tempat jajanan di lingkungan sekolah. Kebiasaan anak mengonsumsi makanan kariogenik membuat anak rentan terhadap karies gigi. Penelitian ini bertujuan untuk mengetahui gambaran status karies pada siswa SMP Negeri 1 Tomohon. Jenis penelitian yang digunakan yaitu penelitian deskriptif dengan pendekatan cross-sectional. Populasi pada penelitian ini ialah siswa SMP Negeri 1 Tomohon dengan pengambilan sampel menggunakan teknik purposive sampling dan terdapat 92 siswa yang menjadi sampel penelitian. Status karies diukur menggunakan indeks DMF-T (decayed, missing, filling-teeth) yang pertama kali diperkenalkan oleh Klein $\mathrm{H}$, Palmer CE, dan Knutson JW pada tahun 1983. Hasil penelitian menunjukkan rata-rata indeks DMF-T pada siswa SMP Negeri 1 Tomohon yaitu 2,26. Simpulan: Status karies siswa SMP Neheri 1 Tomohon berada pada kategori rendah.
\end{abstract}

Kata kunci: status karies, siswa sekolah menengah pertama, DMF-T 
Kesehatan gigi dan mulut merupakan bagian dari kesehatan secara umum yang perlu diperhatikan oleh masyarakat. Karies gigi merupakan penyakit gigi dan mulut yang paling banyak dijumpai di masyarakat. Penyakit ini terjadi pada jaringan keras gigi (email, dentin, dan sementum) yang disebabkan oleh aktivitas jasad renik yang ada dalam suatu karbohidrat yang diragikan. ${ }^{1,2}$

Berdasarkan Riset Kesehatan Dasar (Riskesdas) tahun 2013, indeks DMF-T (decayed, missing, filling-teeth) di Indonesia sebesar 4,6 yang berarti kerusakan gigi penduduk Indonesia 460 gigi per 100 orang dan termasuk dalam kategori tinggi. Indeks DMF-T pada lakilaki sebesar 4,1 termasuk kategori sedang, dan pada perempuan sebesar 4,9 termasuk kategori tinggi. Hasil Riskesdas tahun 2013 berdasarkan kategori karakteristik kelompok usia 12-14 tahun memiliki indeks DMF-T sebesar 1,4 dan termasuk kategori rendah. $^{3}$

Kesehatan gigi dan mulut pada anakanak merupakan faktor penting yang harus diperhatikan sedini mungkin sebab karies gigi yang terjadi pada usia anak-anak dapat mempengaruhi pertumbuhan gigi pada usia selanjutnya. Kebiasaan anak mengonsumsi makanan kariogenik seperti coklat, permen, dan kue-kue manis membuat anak-anak sangat rentan terhadap karies gigi. Dampak yang paling umum terjadi bila anak mengalami karies gigi yaitu menurunnya efektifitas belajar dan nafsu makan yang dapat menyebabkan gangguan pertumbuhan dan kekurangan gizi pada anak. World Health Organization (WHO) merekomendasikan untuk dilakukan pengukuran karies gigi pada anak usia 12 tahun karena menurut WHO pada usia 12 tahun anak lebih mudah diajak berkomunikasi dan diperkirakan semua gigi permanen telah erupsi, kecuali gigi molar tiga. Alasan lain yaitu pada usia tersebut merupakan kelompok yang mudah dijangkau oleh Usaha Kesehatan Gigi Sekolah (UKGS), sehingga usia 12 tahun ditetapkan sebagai usia pemantauan global untuk karies gigi.,
SMP Negeri 1 Tomohon merupakan salah satu sekolah yang cukup besar dengan siswa berusia 11-14 tahun, status sosial ekonomi orang tua siswa yang bervariasi dari rendah sampai menengah, mempunyai standarisasi internasional dalam bidang akademik, dan sarana UKGS yang menunjang pemeriksaan kesehatan gigi di sekolah, tetapi di sekeliling lokasi sekolah terdapat banyak tempat jajanan di luar maupun di dalam lingkungan sekolah yang mungkin menjadi salah satu penyebab terdapat beberapa laporan adanya siswa yang tidak hadir karena keluhan sakit gigi. Pada sekolah ini juga belum pernah dilakukan pemeriksaan dan tidak terdapat data statistik mengenai status karies siswa. Berdasarkan hal tersebut di atas, peneliti tertarik untuk melakukan penelitian mengenai status karies pada siswa SMP Negeri 1 Tomohon.

\section{METODE PENELITIAN}

Penelitian ini bersifat deskriptif dengan pendekatan cross-sectional. Penelitian ini dilaksanakan di SMP Negeri 1 Tomohon pada bulan Agustus 2014. Populasi dalam penelitian ini ialah seluruh siswa SMP Negeri 1 Tomohon berdasarkan criteria inklusi. Besar sampel didapat dengan menggunakan rumus Slovin: ${ }^{6}$

$$
\begin{array}{ll}
\boldsymbol{n}=\frac{\boldsymbol{N}}{\boldsymbol{N}(\boldsymbol{d})^{\mathbf{2}}+\mathbf{1}} & \begin{array}{l}
\text { Keterangan: } \\
\text { n: sampel } \\
\end{array} \\
\begin{array}{l}
\text { N:jumlah } \\
\text { populasi } \\
\text { d: margin }(0,1)
\end{array} \\
\mathrm{n}=793 / 793(0,1)^{2}+1 \\
\mathrm{n}=91,88=92
\end{array}
$$

Kriteria inklusi dalam penelitian ini sebagai berikut: 1) siswa SMP Negeri 1 Tomohon berusia 12-14 tahun yang sudah erupsi gigi permanen kecuali M3; 2) bersedia dengan sukarela untuk dijadikan sebagai subjek penelitian; dan 3) bersikap kooperatif selama pengambilan data.

Penelitian ini menggunakan indeks DMF-T yang disajikan dalam bentuk 
formulir untuk diisi oleh tim peneliti sesuai dengan rumus dan kriteria sebagai berikut :

$\mathrm{DMF}-\mathrm{T}$ rata-rata $=\frac{\text { jumlah } \mathrm{D}+\mathrm{M}+\mathrm{F}}{\text { jumlah semua responden }}$

Kriteria dalam perhitungan DMF-T menurut WHO sebagai berikut; 1) nilai rata-rata $0,0-1,1$ termasuk dalam kategori sangat rendah; 2) nilai rata-rata 1,2 - 2,6 termasuk dalam kategori rendah; 3) nilai rata-rata 2,7 - 4,4 termasuk dalam kategori sedang; 4) nilai rata-rata 4,5 - 6,5 termasuk dalam kategori tinggi; 5) nilai rata-rata $>6,6$ termasuk dalam kategori sangat tinggi.

\section{HASIL PENELITIAN}

1. Karakteristik responden

Terdapat 92 siswa yang menjadi sampel dalam penelitian ini dengan jumlah siswa perempuan yang lebih banyak (55\%) dibandingkan dengan siswa laki-laki (45\%) (Tabel 1), dan distribusi berdasarkan karakteristik usia dapat dilihat dalam Tabel 2.

Tabel 1. Distribusi karakteristik responden berdasarkan jenis kelamin

\begin{tabular}{ccc}
\hline Jenis kelamin & $(\mathrm{n})$ & $(\%)$ \\
\hline Perempuan & 51 & 55 \\
Laki-laki & 41 & 45 \\
\hline Total & 92 & 100 \\
\hline
\end{tabular}

Tabel 2. Distribusi karakteristik responden berdasarkan usia

\begin{tabular}{ccc}
\hline Usia & $(\mathrm{n})$ & $(\%)$ \\
\hline 12 tahun & 27 & 29 \\
13 tahun & 34 & 37 \\
14 tahun & 31 & 34 \\
\hline Total & 92 & 100 \\
\hline
\end{tabular}

Pekerjaan orang tua siswa sebagai PNS juga tambak lebih banyak dibandingkan dengan jenis pekerjaan lain (Tabel 3), sedangkan tingkat pendidikan orang tua siswa yang mencapai jenjang SMA memiliki jumlah yang lebih banyak dibandingkan dengan tingkat pendidikan yang lain (Tabel 4).
Tabel 3. Distribusi karakteristik responden berdasarkan pekerjaan orang tua

\begin{tabular}{ccc}
\hline Pekerjaan orang tua & $(\mathrm{n})$ & $(\%)$ \\
\hline PNS & 44 & 48 \\
Petani & 21 & 23 \\
Swasta & 13 & 14 \\
Polisi & 9 & 10 \\
Dll & 5 & 5 \\
\hline Total & 92 & 100 \\
\hline
\end{tabular}

Tabel 4. Distribusi karakteristik responden berdasarkan pendidikan terakhir orang tua

\begin{tabular}{ccc}
\hline $\begin{array}{c}\text { Pendidikan terakhir } \\
\text { orang tua }\end{array}$ & (n) & (\%) \\
\hline SD & 4 & 4 \\
SMP & 10 & 11 \\
SMA & 56 & 61 \\
Perguruan tinggi & 22 & 24 \\
\hline Total & 92 & 100 \\
\hline
\end{tabular}

2. Status OHI-S

Pemeriksaan status OHI-S yang dilakukan pada siswa SMP Negeri 1 Tomohon menunjukkan sebagian besar subjek (85\%) berada pada kategori baik seperti terlihat pada Tabel 5.

Tabel 5. Distribusi karakteristik responden berdasarkan status OHI-S

\begin{tabular}{ccc}
\hline Status OHI-S & (n) & $(\%)$ \\
\hline Baik & 81 & 85 \\
Sedang & 11 & 15 \\
Buruk & 0 & 0 \\
\hline Total & 92 & 100 \\
\hline
\end{tabular}

3. Status karies

Dari hasil pemeriksaan DMF-T pada siswa SMP Negeri 1 Tomohon, total indeks $\mathrm{D}$ (decayed) berjumlah 165, M (missing) berjumlah 39, dan F (filling) berjumlah empat, sehingga indeks DMF-T rata-rata pada 92 siswa SMP Negeri 1 Tomohon sebesar 2,26 yang didapat dari:

$$
\frac{165+39+4}{92}=2,26
$$

Berdasarkan dari kriteria WHO, indeks ini berada pada kategori status karies 
rendah. Tabel 6 menunjukkan distribusi status karies berdasarkan jenis kelamin.

Tabel 6. Distribusi status karies berdasarkan jenis kelamin

\begin{tabular}{cccccc}
\hline $\begin{array}{c}\text { Jenis } \\
\text { kelamin }\end{array}$ & D & M & F & Skor & Kategori \\
\hline Perempuan & 89 & 24 & 1 & 2,23 & Rendah \\
Laki-laki & 76 & 15 & 3 & 2,29 & Rendah \\
Total & 165 & 39 & 4 & & \\
\hline
\end{tabular}

Data hasil penelitian, indeks DMF-T terlihat baik pada siswa perempuan maupun siswa laki-laki yaitu berada pada kategori rendah. Indeks DMF-T siswa perempuan didapat dari:

$$
\frac{89+24+1}{51}=2,23
$$

Indeks DMF-T pada siswa laki-laki:

$$
\frac{76+15+3}{41}=2,29
$$

Hasil menunjukkan bahwa rata-rata indeks DMF-T pada siswa laki-laki lebih tinggi dibandingkan dengan siswa perempuan. Hasil DMF-T berdasarkan usia terlihat ada perbedaan pada siswa berusia 12 tahun dibandingkan dengan kelompok usia lain (Tabel 7).

Tabel 7. Distribusi status karies berdasarkan usia

\begin{tabular}{cccccc}
\hline $\begin{array}{c}\text { Usia } \\
\text { (tahun) }\end{array}$ & D & M & F & Skor & Kategori \\
\hline 12 & 52 & 12 & 1 & 2,40 & Rendah \\
13 & 58 & 13 & 3 & 2,17 & Rendah \\
14 & 55 & 14 & 0 & 2,22 & Rendah \\
\hline Total & 165 & 39 & 4 & & \\
\hline
\end{tabular}

Rata-rata indeks DMF-T pada siswa usia 12 tahun berada pada kategori rendah diperoleh dengan perhitungan:

$$
\frac{52+12+1}{27}=2,40
$$

Siswa kelompok usia 13 tahun yang juga memiliki rata-rata indeks DMF-T berada pada kategori rendah diperoleh dengan perhitungan :

$$
\frac{58+13+3}{34}=2,17
$$

Rata-rata indeks DMF-T siswa kelompok usia 14 tahun dengan kategori rendah didapat dengan perhitungan :

$$
\frac{55+14+0}{31}=2,22
$$

\section{BAHASAN}

Hasil penelitian ini menunjukkan indeks DMF-T pada siswa SMP Negeri 1 Tomohon berada pada kategori rendah. Karies gigi dapat disebabkan oleh beberapa faktor yaitu host, mikroorganisme, substrat, dan waktu. Faktor-faktor lain yang juga mempengaruhi pembentukan karies gigi yaitu umur, jenis kelamin, kebiasaan makan, penggunaan fluor, oral hygiene, dan status sosial ekonomi. ${ }^{7,8}$

Status karies berada pada kategori rendah dapat dipengaruhi oleh status sosialekonomi. Mayoritas pekerjaan orang tua dari subjek penelitian yaitu Pegawai Negeri Sipil (PNS) dan pendidikan terakhir orang tua paling banyak berada pada jenjang SMA. Data tersebut menunjukkan rata-rata siswa di SMP Negeri 1 Tomohon berasal dari keluarga dengan status golongan sosial-ekonomi menengah. Sebuah penelitian di Swedia menunjukkan adanya hubungan status sosial-ekonomi dengan kejadian karies gigi pada anak 12-14 tahun yaitu anak yang berasal dari keluarga golongan sosial-ekonomi yang rendah memilik resiko karies gigi yang lebih tinggi dibandingkan dengan anak yang berasal dari keluarga golongan sosial ekonomi menengah dan tinggi, sehingga dapat dikatakan peran pendidikan orang tua tentang kebersihan gigi dan mulut dapat mempengaruhi status karies pada anak. Orang tua yang memiliki pengetahuan kesehatan gigi dan mulut yang baik juga 
memiliki anak dengan status karies yang lebih rendah dibandingkan dengan orang tua dengan pengetahuan kesehatan gigi dan mulut yang kurang baik. ${ }^{9}$

Hasil penelitian ini juga sama dengan hasil penelitian di Zimbabwe pada anak usia 12 tahun yang menunjukkan status karies pada anak yang berasal dari daerah pedesaan dengan golongan sosial ekonomi rendah memiliki status karies yang lebih tinggi dibandingkan dengan anak yang berasal dari daerah perkotaan dengan golongan status sosial ekonomi yang lebih tinggi. Penelitian yang juga dilakukan pada anak usia 12 tahun di Tomohon menunjukkan bahwa status karies anak yang berasal dari keluarga golongan sosial ekonomi rendah memiliki resiko karies gigi yang tinggi. ${ }^{10,11}$

Terdapat perbedaan hasil pengukuran indeks DMF-T pada siswa laki-laki dan siswa perempuan yaitu status karies pada siswa laki-laki memiliki rata-rata lebih tinggi dibandingkan dengan siswa perempuan. Hasil penelitian ini berbeda dengan hasil sebuah penelitian yang dilakukan di Jepang bahwa persentase karies gigi pada anak perempuan lebih tinggi dibandingkan dengan anak laki-laki. Dalam penelitian tersebut disebutkan bahwa usia 12 tahun merupakan masa peralihan dari anak-anak menjadi remaja yang mengakibatkan peningkatan karies pada anak perempuan karena dipengaruhi oleh erupsi gigi yang cepat serta perubahan hormonal. Waktu erupsi gigi anak perempuan lebih cepat satu sampai enam bulan dibandingkan dengan anak laki-laki yang disebabkan oleh faktor hormonal berupa hormon esterogen. Hormon esterogen berperan dalam pertumbuhan dan perkembangan pada saat anak perempuan mencapai pubertas. Selain itu, komposisi saliva pada masa pubertas dan menstruasi juga dapat mengalami perubahan. Kebiasaan anak perempuan yang lebih cenderung menyukai makanan manis dibandingkan dengan anak laki-laki juga merupakan salah satu faktor peningkatan karies yang lebih tinggi pada anak perempuan. Faktor-faktor inilah yang mungkin menjadi salah satu faktor penyebab peningkatan karies gigi pada anak perempuan. Namun, pada hasil penelitian ini menunjukkan bahwa anak laki-laki memiliki rata-rata indeks DMF-T yang lebih tinggi dibandingkan anak perempuan. Hal ini mungkin disebabkan kecenderungan anak perempuan yang lebih memperhatikan kebersihan gigi dan mulut dibandingkan dengan anak laki-laki. ${ }^{12,13,14}$

Data dari Riskesdas tahun 2013 menunjukkan indeks DMF-T meningkat seiring bertambahnya usia. Gigi yang paling awal erupsi lebih rentang terhadap karies. Hasil penelitian menunjukkan ratarata indeks DMF-T pada siswa usia 12 tahun lebih tinggi dibandingkan pada siswa usia 13 tahun dan 14 tahun. Hal ini disebabkan pada usia yang lebih dewasa memiliki pengetahuan yang lebih baik sehingga lebih mengerti tentang pemeliharaan kesehatan gigi dan mulut yang baik. ${ }^{3,11,13}$

Berdasarkan hasil tanya jawab langsung dengan responden dan pengamatan peneliti, kebanyakan siswa di SMP Negeri 1 Tomohon mengonsumsi jajanan yang berada di dalam maupun di luar sekolah. Lingkungan sekolah yang memiliki banyak warung dan tempat makan, juga banyaknya pedagang kaki lima yang berjualan di sekitar pada jam istirahat berpengaruh pada peningkatan terjadinya karies gigi pada siswa.

Dalam penelitian ini diukur juga status OHI-S dan diperoleh bahwa status OHI-S baik dan rata-rata indeks DMF-T berada pada kategori rendah. Kebersihan gigi dan mulut sangat besar pengaruhnya untuk mencegah terjadinya karies gigi. Kurangnya kebersihan gigi dan mulut dapat menyebabkan terjadinya penimbunan plak dan sisa-sisa makanan. Karbohidrat dapat mengalami peragian, terutama sukrosa, merupakan substrat utama untuk menghasilkan asam-asam metabolik oleh bakteri-bakteri yang terjerat. Plak menetralisasi asam mencegah penyebaran bakteri. Asam akan menghancurkan lapisan email gigi dengan jalan dekalsifikasi, yaitu menghilangkan zat kapur gigi dan 
terjadilah karies gigi. ${ }^{14}$ Penelitian lain tentang hubungan status OHI-S dengan DMF-T pada anak usia 12-14 tahun di Medan menunjukkan bahwa anak yang memiliki status OHI-S yang baik mempunyai DMF-T yang berada pada kategori rendah. ${ }^{15}$ Hal ini mungkin disebabkan oleh sebagian besar pekerjaan orang tua adalah PNS yang memiliki asuransi kesehatan, sehingga anak-anak dapat memperoleh kontrol kesehatann gigi dan mulut secara berkala. Hasil penelitian di Skotlandia juga menunjukkan adanya perubahan status karies gigi dari tinggi menjadi rendah pada anak mudah memperoleh pelayanan kesehatan gigi dan mulut. ${ }^{16,17}$ Hal ini yang dapat menjelaskan walaupun lingkungan sekolah memiliki banyak tempat jajanan yang membuat siswa rentan terhadap karies, tapi indeks DMF-T menunjukkan siswa SMP Negeri 1 Tomohon berada pada kategori rendah yang artinya rata-rata siswa hanya memiliki dua gigi berlubang.

\section{SIMPULAN}

1. Status karies pada siswa SMP Negeri 1 Tomohon berada pada kategori rendah.

2. Status karies siswa SMP Negeri 1 Tomohon berdasarkan kelompok jenis kelamin, pada siswa laki-laki maupun siswa perempuan berada pada kategori rendah.

3. Status karies siswa SMP Negeri 1 Tomohon berdasarkan kelompok usia 12 tahun, 13 tahun, dan 14 tahun berada pada kategori rendah.

4. Status OHI-S pada siswa SMP Negeri 1 Tomohon berada pada kategori baik.

\section{SARAN}

1. Sekolah perlu terus meningkatkan upaya untuk menjaga kesehatan gigi dan mulut bagi siswa melalui pemberian pendidikan tentang cara menjaga kesehatan gigi dan mulut.

2. Peran orang tua perlu diperhatikan dengan memberikan pendidikan tentang cara menjaga kesehatan gigi dan mulut anak dan mengantar anak secara berkala untuk melakukan pemeriksaan gigi dan mulut.

3. Untuk mencegah karies gigi pada siswa dapat dilakukan sosialisasi tentang dokter gigi keluarga. Bagi orang tua siswa yang kurang mampu dapat melakukan perawatan gigi dan mulut melalui bantuan pemerintah berupa Badan Penyelenggara Jaminan Sosial (BPJS)

\section{DAFTAR PUSTAKA}

1. Fejerskov O, Kidd E. Dental caries the disease and its clinical management $2^{\text {nd }}$ ed. New York: Oxford University Press. 2008

2. Jose O, Cortes G, Carlo E, Solis M, Juan P, Jorge A et al. Dental caries' experience, prevalence and severity in mexican adolescents and young adults. Mexico: Sauld Publica; 2009: 83-84.

3. Riset Kesehatan Dasar. Laporan kesehatan gigi dan mulut; 2013.

4. Sondang $\mathbf{P}$, Hamada T. Menuju gigi dan mulut sehat. Medan: USU Press, 2008; p. 415, 424.

5. Petersen PE. The world oral health report 2003. Continuous improvement of oral health in the $21^{\text {st }}$ century - the approach of the WHO Global Oral Health Programme. Geneva: World Health Organization, 2003.

6. Sevilla, Consuelo G. Research methods. Rex Printing Company: Quenzon City. 2007.

7. Prabhu S, John J. Dental caries prevalence among 12 year old school children from urban and rural areas in Tamin Nadu, India-a comparative study. Ejournal of Dentistry. 2013.

8. Dental health: klasifikasi kavitas karies menurut GV. Black. [serial online] 2012 [cited Maret 2014]. Available from URL: http://asiabussinescenter.blogspot.co $\mathrm{m} / 2012 / 05 /$ dental-health-klasifikasikav itas.html.

9. Kallestal C, Wall S. Socio-economic effect on caries, incidence data among Swedish 12-14-year-olds. Swedia. 2002

10.Wala HC, Wicaksono DA, Tambunan E. Gambaran status karies gigi anak usia 
11-12 tahun pada keluarga pemegang jamkesmas di Kelurahan Tumatangtang I Kecamatan Tomohon Selatan. Manado: Universitas Sam Ratulangi. 2013.

11.Mafuvadze B, Mahachi L, Mafuvadze B. Dental caries and oral health practice among 12 years old children from low socio-economic status background in Zimbabwe. Zimbabwe: The Pan African American Journal. 2013.

12.Fujita H, Asakura K, Ogura M. Age and sex-related dental caries prevalence in Japanese from the jomon period. Journal of Oral Biosciences. 2007: 198-204.

13.Hidayati L. Hubungan karakteristik keluarga dan kebiasaan konsumsi makanan kariogenik dengan keparahan karies gigi anak sekolah dasar [Skripsi]. Semarang: Universitas Diponegoro, 2005.

14.Ireland $\mathbf{R}$. Clinical textbook of dental hygiene and therapy. London: a Blackwell Publishing Company, 2006; 22.

15.Sihombing J. Karakteristik penderita karies yang berobat di RSU Dr. Pirngadi Medan [Skripsi]. Medan: Universitas Sumatera Utara. 2009

16.Yusuf M. Hubungan status OHI-S dengan DMF-T pada anak usia 12-14 tahun [Skripsi]. Medan: Universitas Sumatra Utara, 2011.

17. Chambers S. Public health and dental caries in young children in deprived communities in Scotland. Dundee: Universities Medical Journal, 2002. 